\title{
Serum biochemical assessment of hepatic and renal functions of rats during oral exposure to glyphosate with zinc
}

\author{
Emmanuel Vandi Tizhe • Najume Dogon-Giginya Ibrahim • Mohammed Yakasai Fatihu • \\ Ikechukwu Onyebuchi Igbokwe • Butcher-Danladi Jonathan George • \\ Suleiman Folorunsho Ambali • Joshua Mallum Shallangwa
}

Received: 18 October 2012 / Accepted: 3 April 2013 / Published online: 3 May 2013

(C) The Author(s) 2013. This article is published with open access at Springerlink.com

\begin{abstract}
A subchronic toxicity study was carried out to assess hepatic and renal functions of rats during oral exposure to glyphosate with zinc for the period of 8 weeks. Forty-eight Wistar rats used for the study were randomized into six groups of eight Wistar rats each, and each group had equal number of male and female Wistar rats. The Wistar rats administered with distilled water at $2 \mathrm{ml} / \mathrm{kg}$ body weight served as the control group (DW); others were administered with zinc at $50 \mathrm{mg} / \mathrm{kg}$ body weight (Z) group, glyphosate at $375 \mathrm{mg} / \mathrm{kg}$ body weight $(\mathrm{G})$ group, a combination of zinc and glyphosate at 50 and $375 \mathrm{mg} / \mathrm{kg}$ body weight, respectively $(\mathrm{Z}+\mathrm{G})$, group, glyphosate at $14.4 \mathrm{mg} / \mathrm{kg}$ body weight (GC) group, and a combination of zinc and glyphosate at 50 and $14.4 \mathrm{mg} / \mathrm{kg}$ body weight, respectively $(\mathrm{Z}+\mathrm{GC})$, group. At the end of the study, blood samples were collected from each rats; from which, sera samples were obtained and assayed for total protein, albumin, alanine and aspartate aminotransferases, alkaline phosphatase, $\mathrm{Na}^{+}, \mathrm{K}^{+}, \mathrm{Cl}^{-}$, $\mathrm{HCO}_{3}^{-}, \mathrm{Ca}^{2+}, \mathrm{PO}_{4}^{-}$, urea and creatinine using autoanalyzer,
\end{abstract}

E. V. Tizhe $(\triangle) \cdot$ N. D.-G. Ibrahim $\cdot$ M. Y. Fatihu

Department of Pathology, Faculty of Veterinary Medicine,

Ahmadu Bello University, Zaria, Kaduna, Nigeria

e-mail: comradevandi@yahoo.com

\section{O. Igbokwe}

Department of Pathology, Faculty of Veterinary Medicine,

University of Maiduguri, Maiduguri, Nigeria

B.-D. J. George

Department of Parasitology and Entomology, Faculty of Veterinary

Medicine, Ahmadu Bello University, Zaria, Kaduna, Nigeria

\section{S. F. Ambali}

Department of Pharmacology, Faculty of Veterinary Medicine,

Ahmadu Bello University, Zaria, Kaduna, Nigeria

J. M. Shallangwa

Veterinary Clinic, Ministry for Livestock and Production,

Song LGA, Adamawa, Nigeria and globulin was calculated. The albumin concentration was significantly high $(p<0.05)$ in GC group compared to DW group, and this change was ameliorated following supplementation with zinc. The total protein and globulin concentrations did not differ significantly between the groups ( $p>$ 0.05 ), and the relative changes were ameliorated by supplementation with zinc. The alkaline phosphatase activity was relatively low in GC group; however, supplementation with zinc in $\mathrm{Z}+\mathrm{GC}$ group made it to be significantly high $(p<$ $0.05)$ compared to GC group. The alanine and aspartate aminotransferases in G and GC groups were relatively high compared to DW group, which were ameliorated by supplementation with zinc. The relatively low $\mathrm{Ca}^{2+}$ concentration in $\mathrm{G}$ and $\mathrm{GC}$ groups compared to DW were ameliorated in $\mathrm{Z}+\mathrm{G}$ group, and it was significantly high in $\mathrm{Z}+\mathrm{GC}$ group at $p<0.01$ compared to DW, $p<0.001$ compared to $\mathrm{G}$ and GC groups and $p<0.05$ compared to $\mathrm{Z}+\mathrm{G}$ group. There were only slight changes in the electrolytes concentrations $\mathrm{CNa}^{+}$, $\mathrm{K}^{+}, \mathrm{Cl}^{-}, \mathrm{HCO}_{3}^{-}$and $\mathrm{PO}_{4}^{-}$), which were differentially ameliorated by zinc supplementation. The reasons for the various changes recorded were discussed. It was concluded that subchronic oral exposure to glyphosate caused both hepatic and renal functions toxicity in rats, which were ameliorated by zinc supplementation.

Keywords Serum biochemical $\cdot$ Hepatic $\cdot$ Renal . Subchronic $\cdot$ Glyphosate $\cdot$ Zinc

\section{Introduction}

Glyphosate, the active ingredient which is $48 \%$ acid equivalent of the 180 propylamine salt of glyphosate (phosphonomethyl glycine), is used as a non-selective herbicide and for control of a great variety of annual, biennial and perennial grasses, broad-leaved weeds and woody 
shrubs in orchards, vineyards, conifer plantations and many plantation crops. It is perhaps the most important herbicide ever developed (World Health Organization 1994). Glyphosate has low persistence, and because repeated applications of this herbicide are practiced for the control of weeds in agricultural fields, large quantities find their way into water bodies. The indiscriminate use of the herbicide therefore makes it a potential source of danger to animals, not only in grazing fields but also in the water bodies (Ayoola 2008).

The manufacturers of glyphosate-based herbicides claim their "low toxicity and environmental friendliness"; however, evidence indicates that the herbicide may not be as safe as previously thought (Franz et al. 1997). As a herbicide, glyphosate works by being absorbed into the plant mainly through its leaves, but also through soft stalk tissues. It is then transported throughout the plant where it acts on various enzyme systems, inhibiting amino acid metabolism in what is known as shikimic acid pathway. This pathway exists in higher plants and microorganisms but not in animals. Plants treated with glyphosate slowly die over a period of days or weeks, and because the chemical is transported throughout the plant, no part survives (Cox 1995; Malik et al. 1989). In animals, mechanisms of toxic action have not been fully elucidated. A reduced respiratory control ratio, enhanced ATPase activity and stimulated oxygen uptake rate were observed in liver mitochondria obtained from rats given glyphosate. Based on these results, the authors suggested that these toxicological effects may be primarily due to the uncoupling of oxidative phosphorylation (Olurunsogo et al. 1979).

Oxidative stress has been implicated in the molecular mechanisms of glyphosate toxicity (Beuret et al. 2004). The body responds to oxidative stress by evoking the enzymatic defence system within the body (Vivian and Claudia 2007).

In pure chemical terms, glyphosate is an organophosphate (OP) in that it contains carbon and phosphorus. However, it does not affect the nervous system in the same way as organophosphate insecticides, and is not a cholinesterase inhibitor (Rebecca et al. 1991). In addition, there is paucity of information on the toxicity of glyphosate-based herbicide, Roundup ${ }^{\circledR}$, especially on how it affects animal health (Modesto and Martinez 2010).

Zinc is an essential trace mineral, which means that it must be obtained from the diet since the body cannot produce enough. It is the second most abundant mineral in the body, stored primarily in the muscle; it is also found in high concentrations in red and white blood cells, the retina of the eye, bones, skin, kidneys, liver and pancreas (Belongia et al. 2001). Zinc plays an important role in the immune system, regulation of appetite, stress level, taste and smell (McClain et al. 1992). Two antioxidant mechanisms of zinc have been identified: zinc ions may replace redox active molecules such as iron and copper at critical sites in cell membranes and proteins; alternatively, zinc ions may induce the biosynthesis of metallothionein, sulfhydryl-rich proteins that protect against free radicals (Rostan et al. 2002). Owing to its mechanisms of action, zinc has been used in the amelioration of organophosphate (chlorpyrifos)-induced alterations in haematological and serum biochemical changes in Wistar rats (Ambali et al. 2010a). It has also been used to attenuate oxidative stress in arsenic- and cadmium-exposed rats (Kumar et al. 2010; Amara et al. 2008).

\section{Materials and methods}

Experimental animals

Forty-eight Wistar rats, $160-200 \mathrm{~g}$ body weight, were purchased from the Animal House of the Department of Veterinary Physiology and Pharmacology, Ahmadu Bello University, Zaria. They were housed in the Animal Room of the Department of Veterinary Pathology and Microbiology for 2 weeks before the commencement of the research, which lasted for 8 weeks. The rats were fed appropriately using standard rat chow, and water was provided ad libitum.

\section{Chemical source}

Glyphosate (Bushfire ${ }^{\circledR}$, Monsanto Europe SA), which contains $360 \mathrm{~g}$ glyphosate $/ \mathrm{L}$ in the form of $441 \mathrm{~g} / \mathrm{L}$ potassium salt and zinc chloride with the following specification: MW 136.29, Cat No. 45114 and Lot No. 11601 (BDH Chemical Ltd., Poole, England), is a white deliquescent granule with minimum assay of $98.0 \%$, and maximum limits of impurities: acid-insoluble matter $0.005 \%$, zinc oxide $(\mathrm{ZnO}) 1.2 \%$, sulphate $\left(\mathrm{SO}_{4}\right) 0.002 \%$, cadmium $(\mathrm{Cd}) 0.0005 \%$, calcium (Ca) $0.001 \%$, copper $(\mathrm{Cu}) 0.0005 \%$, iron $(\mathrm{Fe}) 0.001 \%$, lead $(\mathrm{Pb}) 0.001 \%$, magnesium $(\mathrm{Mg}) 0.001 \%$, potassium (K) $0.001 \%$ and sodium $0.001 \%$ were purchased from a reputable chemical store in Zaria.

Experimental design

Subchronic toxicity study

Forty-eight adult male and female Wistar rats were randomly divided into six groups of eight rats each as described below:

Group I (DW): Served as the control and were administered $2 \mathrm{ml} / \mathrm{kg}$ of distilled water daily

Group II (Z): Were administered zinc at the dose rate of $50 \mathrm{mg} / \mathrm{kg}$ body weight (Ambali et al. 2010a)

Group III (G): Were administered glyphosate (10\% of the $\mathrm{LD}_{50}$ ), which is $3,750 \mathrm{mg} / \mathrm{kg}$ as reported by Tizhe (2012) 
Group IV $(\mathrm{Z}+\mathrm{G})$ : Were administered zinc at $50 \mathrm{mg} / \mathrm{kg}+$ glyphosate $\left(10 \%\right.$ of the $\left.\mathrm{LD}_{50}\right)$

Group V (GC): Were administered glyphosate at the concentration of 1:50 glyphosate and distilled water, respectively

Group VI $(\mathrm{Z}+\mathrm{G})$ : Were administered zinc at $50 \mathrm{mg} / \mathrm{kg}+$ glyphosate at the concentration of 1:50 glyphosate and distilled water, respectively

The dose regimens were administered per os once daily for a period of 8 weeks. The rats were monitored for clinical signs and death.

\section{Serum biochemical analysis}

Another set of blood sample ( $5 \mathrm{ml}$ each) was collected from each rat into clean test tubes. The blood samples were incubated for $30 \mathrm{~min}$, and thereafter centrifuged at $800 \times \mathrm{g}$ for $10 \mathrm{~min}$ to obtain the sera. The sera were analysed for aspartate aminotransferase, alanine aminotransferase and alkaline phosphatase. Other parameters measured included total serum proteins and albumin, electrolytes, urea and creatinine. They were determined using Bayer Express plus Clinical Chemistry Autoanalyser (Bayer ${ }^{\circledR}$ Germany), but the globulin concentrations were calculated by subtracting the albumin concentrations from the total proteins.

\section{Results and discussion}

Effect of the treatments on serum protein, albumin and globulin concentrations

The effect of the treatments on serum protein, albumin and globulin concentrations is shown in Fig. 1. There was no significant change in serum protein concentration between the groups. However, there was a relatively low total protein concentration $(7.6 \%)$ in $\mathrm{Z}+\mathrm{GC}$ group when compared to $\mathrm{DW}$ group. On the other hand, there was a relative high total protein concentration in $\mathrm{Z}(11.3 \%), \mathrm{Z}+\mathrm{G}(0.7 \%), \mathrm{G}(0.5 \%)$ and GC $(0.3 \%)$ groups, respectively, when compared to DW group.

There was a significantly high $(p<0.05 ; 34.7 \%)$ albumin concentrations in GC group when compared to DW group. On the other hand, there was a relatively high albumin concentration in $Z(19.1 \%), G(15.2 \%), Z+G(11.1 \%)$ or $\mathrm{Z}+\mathrm{GC}(5.8 \%)$ group when compared to DW group.

The globulin concentrations showed no significant change between the groups. However, there was a relatively high $(8.5 \%)$ globulin concentration in $\mathrm{Z}$ group when compared to DW. On the other hand, there was a relatively low globulin concentration in $\mathrm{Z}+\mathrm{G}(3.1 \%), \mathrm{G}(3.7 \%), \mathrm{Z}+\mathrm{GC}$ $(12.2 \%)$ and GC (17.9\%) groups, respectively, when compared to DW group.

\section{Effect of the treatments on serum enzymes}

The activities aspartate aminotransferase (AST) were not significantly different $(p>0.05)$ between the groups. However, there was relatively low AST in Z $(5.80 \%)$ and $\mathrm{Z}+\mathrm{G}$ $(18.10 \%)$ group when compared to DW group. On the other hand, there was a relative decrease in AST activity in DW group compared to those recorded in $\mathrm{G}(33.5 \%)$, GC $(13.0 \%)$ or $\mathrm{Z}+\mathrm{GC}(9.8 \%)$ group.

There were no significant changes in the activities of alanine aminotransferase (ALT) between the groups. However, there was a relatively low (11.9\%) ALT activity in Z+ GC group when compared to DW group. On the other hand, there was a relatively high ALT activity in Z (44.90\%), GC (35.50\%), Z+G (17.00\%) or G (11.60\%) group when compared to DW group.
Fig. 1 Effect of subchronic exposure to distilled water $(D W)$, zinc $(Z)$ and glyphosate at $10 \%$ of the $\operatorname{LD}_{50}(G)$ and at 1:50 glyphosate and distilled water $(G C)$ on changes in total protein, albumin and globulin concentrations in Wistar rats, $a=p<0.05$ versus DW group

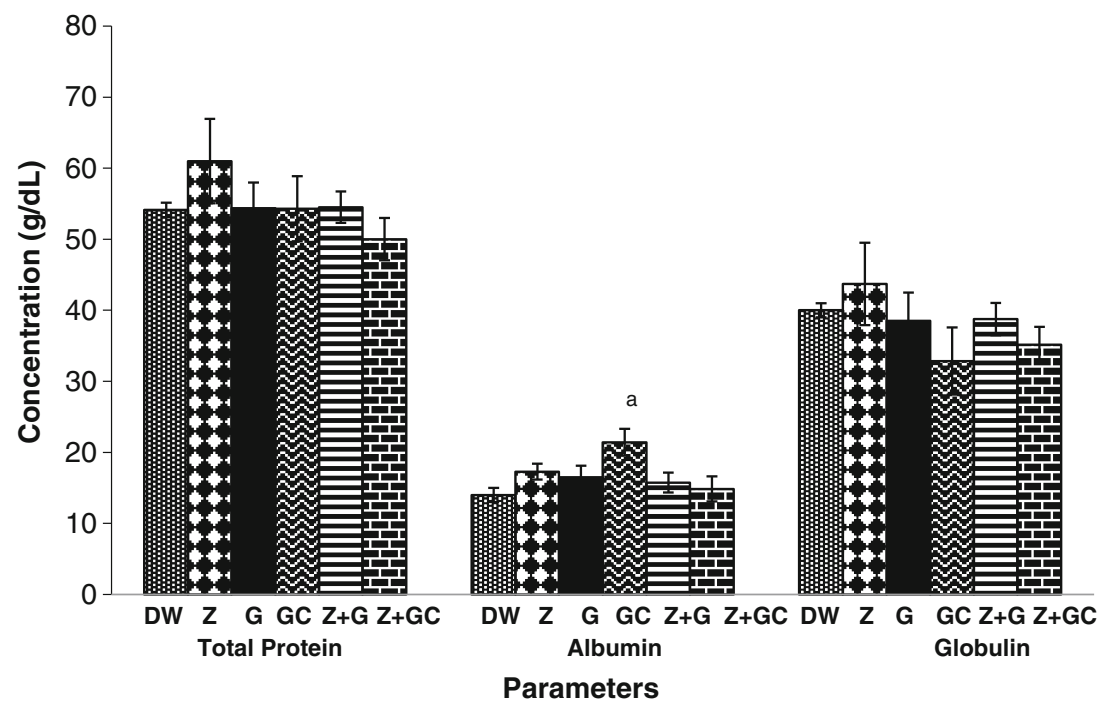


The activity of alkaline phosphatase was significantly higher $(p<0.05 ; 60.60 \%)$ in $\mathrm{Z}+\mathrm{GC}$ group when compared to $\mathrm{GC}$ group. On the other hand, there was a relatively low ALP activity in G (31.00\%), Z (17.70\%) and $Z+G(4.20 \%)$ groups, respectively, when compared to DW group (Fig. 2).

Effect of the treatments on serum electrolyte concentrations

There were no significant changes $(p>0.05)$ in the $\mathrm{Na}^{+}$ concentration among the groups. However, there was a relatively low $\mathrm{Na}^{+}$concentration in $\mathrm{Z}+\mathrm{G}(11.70 \%), \mathrm{Z}+$ GC (10.30\%), Z (8.80\%), GC (8.50\%) and G (6.20\%) groups, respectively, when compared to DW group.

The difference in the $\mathrm{K}^{+}$concentration among all the groups was not significant $(p>0.05)$. However, there was a relatively low $\mathrm{K}^{+}$concentration in $\mathrm{Z}+\mathrm{G}(8.10 \%)$ group when compared to DW group. On the other hand, there was a relatively high $\mathrm{K}^{+}$concentration in $\mathrm{G}(20.90 \%)$, Z+ GC $(10.60 \%)$, GC $(8.20 \%)$ or Z $(0.60 \%)$ group when compared to DW group.

There were no significant changes $(p>0.05)$ in the $\mathrm{Cl}^{-}$ concentration among all the groups. However, there was a relatively low $\mathrm{Cl}^{-}$concentration in $\mathrm{Z}(8.50 \%), \mathrm{GC}(5.70 \%)$, $\mathrm{G}(5.50 \%), \mathrm{Z}+\mathrm{G}(3.10 \%)$ and $\mathrm{Z}+\mathrm{GC}(0.50 \%)$ groups, respectively, when compared to DW group.

The differences in the $\mathrm{HCO}_{3}^{-}$concentration among the groups were not significant $(p>0.05)$. However, there was no change in the $\mathrm{HCO}_{3}^{-}$concentration between $\mathrm{GC}$ group and DW group. On the other hand, there was a relatively low $\mathrm{HCO}_{3}^{-}$concentration in $\mathrm{Z}(9.40 \%)$ or $\mathrm{Z}+\mathrm{G}(7.40 \%)$ group and a relatively high $\mathrm{HCO}_{3}^{-}$concentration in $\mathrm{G}$ $(18.70 \%)$ or $\mathrm{Z}+\mathrm{GC}(4.70 \%)$ group when compared to DW group.
There was a highly significant rise $(p<0.01)$ in $\mathrm{Ca}^{+}$ concentration in $\mathrm{Z}+\mathrm{GC}$ group when compared to DW and $\mathrm{Z}$ groups, respectively. There was also a very highly significant rise $(p<0.001)$ in $\mathrm{Z}+\mathrm{GC}$ group compared to those recorded in $\mathrm{G}$ and $\mathrm{GC}$ groups, respectively. In addition, there was a significant rise $(p<0.05 ; 27.40 \%)$ in $\mathrm{Ca}^{2+} \mathrm{Z}+$ $\mathrm{GC}$ group compared to $\mathrm{Z}+\mathrm{G}$ group.

There was no significant change $(p>0.05)$ in the $\mathrm{PO}_{4}$ concentrations in between the groups. However, there was a relatively high $\mathrm{PO}_{4}$ concentration in $\mathrm{GC}(10.80 \%)$, G $(10.60 \%), Z+G(6.70 \%), Z(6.10 \%)$ and $Z+G C$ ( $2.50 \%)$ groups, respectively, when compared to DW group (Fig. 3a, b).

Effect of the treatments on serum urea concentration

There was no significant change $(p>0.05)$ in the urea concentration between the groups. However, there was a relatively low urea concentration in $\mathrm{Z}+\mathrm{GC}(20.50 \%)$ group when compared to DW group. On the other hand, there was a relatively high urea concentration in $\mathrm{Z}+\mathrm{G}(22.50 \%), \mathrm{G}$ $(11.50 \%)$, GC (9.90\%) and Z (6.20\%) groups, respectively, compared to DW group (Fig. 4).

\section{Effect of the treatments on serum creatinine concentration}

There was no significant change $(p>0.05)$ in creatinine concentration between the groups. However, there was a relatively low creatinine concentration in $\mathrm{Z}+\mathrm{GC}(18.80 \%)$ group when compared to DW group. On the other hand, there was a relatively high creatinine concentration in $\mathrm{G}$ (15.00\%), GC (14.90\%), Z (7.90\%) and Z+G (5.70\%) groups, respectively, when compared to DW group (Fig. 5).
Fig. 2 Effect of subchronic exposure to distilled water $(D W)$, zinc $(Z)$ and glyphosate at $10 \%$ of the $\operatorname{LD}_{50}(G)$ and at 1:50 glyphosate and distilled water $(G C)$ changes in serum enzymes activities in Wistar rats, $a=p<0.05$ versus GC

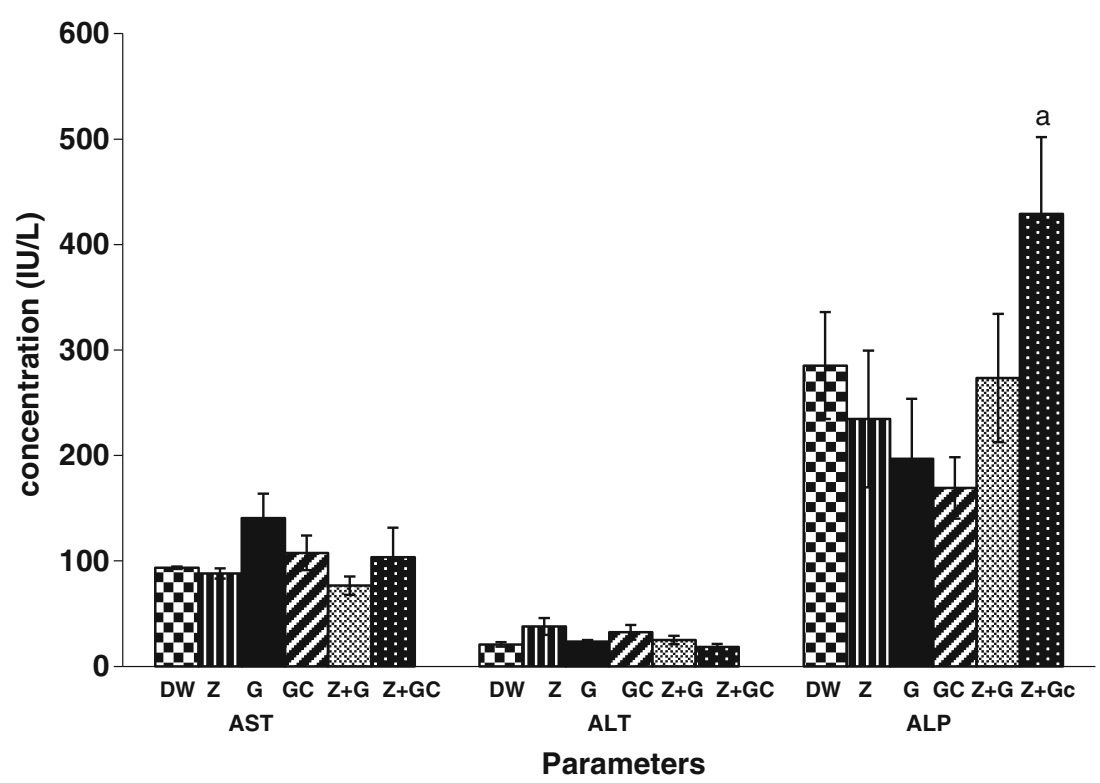

Springer 
Fig. 3 a Effect of subchronic exposure to distilled water $(D W)$, zinc $(Z)$ and glyphosate at $10 \%$ of the $\operatorname{LD}_{50}(G)$ and at 1:50 glyphosate and distilled water $(G C)$ on changes in serum electrolytes

concentrations in Wistar rats. b Effect of subchronic exposure to distilled water $(D W)$, zinc $(Z)$ and glyphosate at $10 \%$ of the $\mathrm{LD}_{50}(G)$ and at $1: 50$ glyphosate and distilled water $(G C)$ changes in serum electrolytes in Wistar rats. $a=p$ $<0.01$ versus DW and $\mathrm{Z}, p<$ 0.001 versus $\mathrm{G}$ and $\mathrm{GC}, p<0.05$ versus $\mathrm{Z}+\mathrm{G}$

The result of this study showed no significant difference $(p>0.05)$ in total protein concentration in the $\mathrm{G}$ and $\mathrm{GC}$

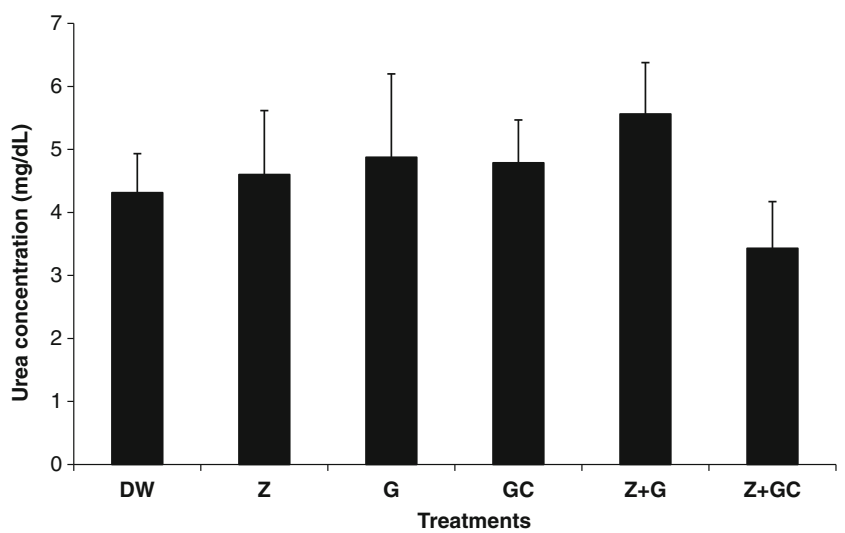

Fig. 4 Effects of subchronic exposure to distilled water $(D W)$, zinc $(Z)$ and glyphosate at $10 \%$ of the $\operatorname{LD}_{50}(G)$ and at $1: 50$ glyphosate and distilled water $(G C)$ on changes in serum urea concentration in Wistar rats
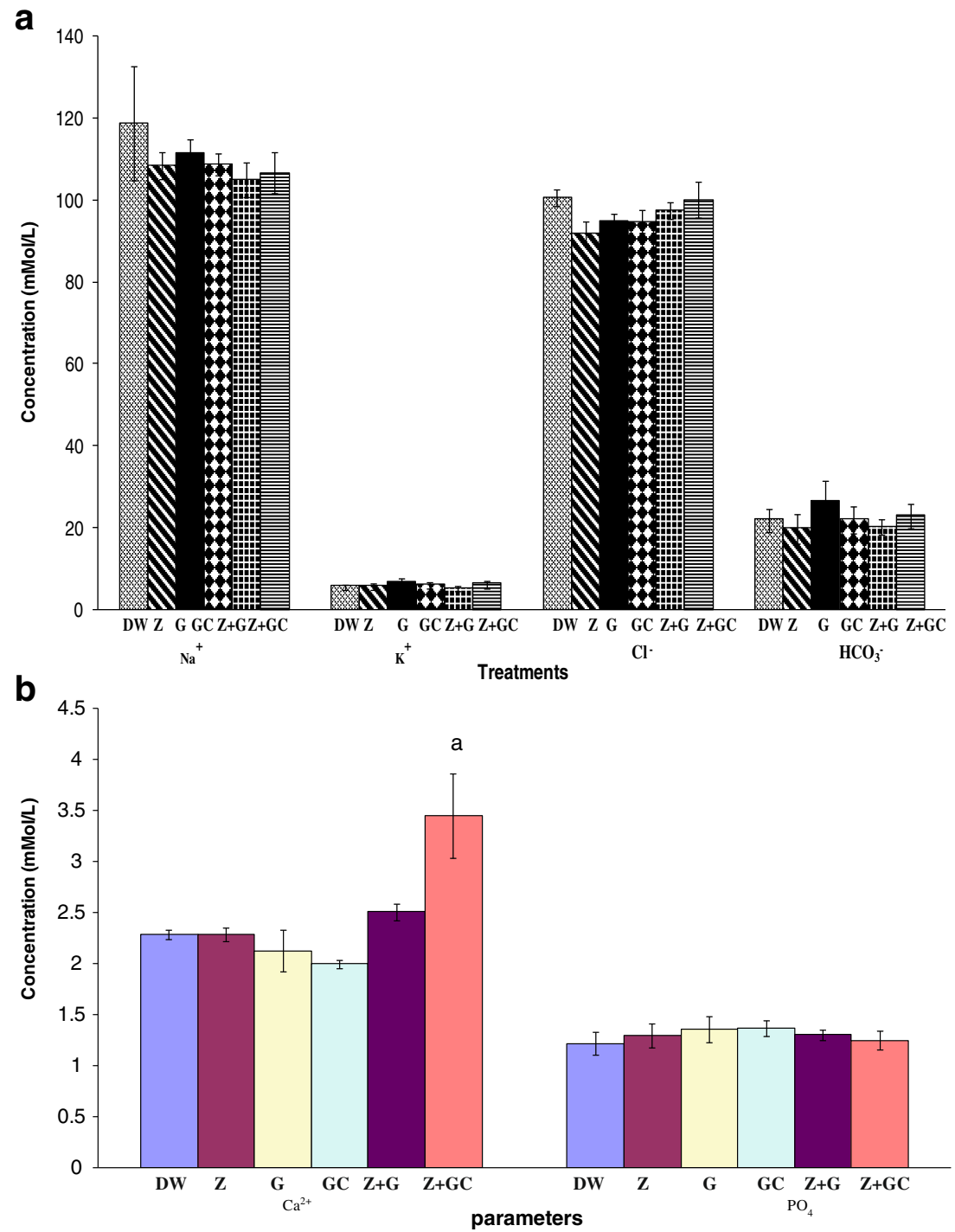

groups compared to the DW group. This is similar to the result obtained by El-Shenawy (2009) who reported that

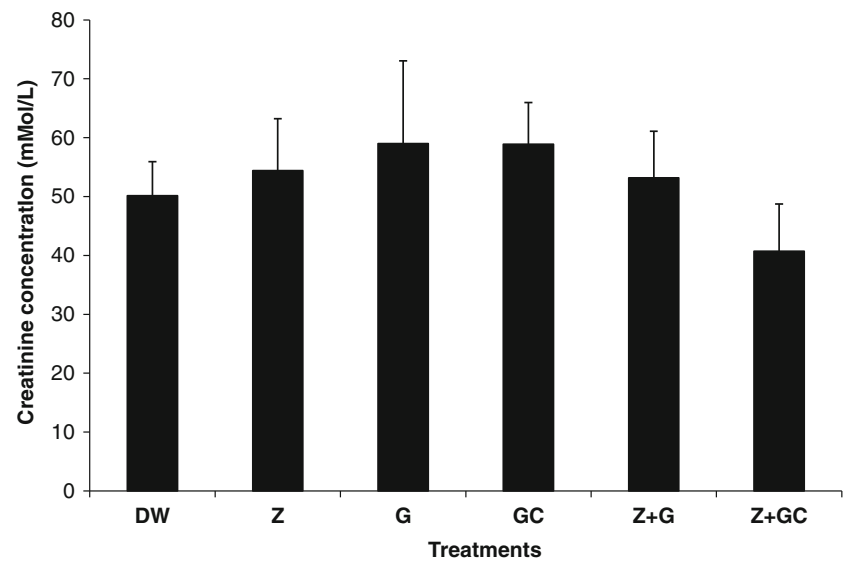

Fig. 5 Effect of subchronic exposure to distilled water $(D W)$, zinc $(Z)$ and glyphosate at $10 \%$ of the $\operatorname{LD}_{50}(G)$ and at 1:50 glyphosate and distilled water $(G C)$ on serum creatinine concentration in Wistar rats 
Roundup ${ }^{\circledR}$ and glyphosate did not significantly affect total protein concentration after 2 weeks of exposure in rats. There were relatively higher total protein concentrations in the $\mathrm{Z}$ and the $\mathrm{Z}+\mathrm{G}$ groups, possibly due to the antioxidant properties of zinc. The total protein concentration in the $\mathrm{Z}+$ GC showed a relatively low total protein concentration compared to the DW group. The reason for the relatively low total protein in the $\mathrm{Z}+\mathrm{GC}$ group is not known especially in the light of the relative increase in the WBC count in the group.

There was a significantly high albumin concentration in the GC group compared to the DW group and a relatively high albumin concentration in the $G$ group compared to the DW group. It was found that Roundup ${ }^{\circledR}$ and glyphosate caused a relatively high albumin concentration in rats (El-Shenawy 2009). The reason for the high albumin level in the blood as observed in the glyphosate ( $\mathrm{G}$ and $\mathrm{GC}$ )-treated groups relative to the DW group was not known. However, Vosilenko and Grebenev (1990) reported that decrease in the serum albumin might be indicative of renal inability that resulted in albuminuria. The relatively high level of albumin in the blood as observed in the present study could be attributed to the observed renal damage. There was a relatively low albumin concentration in $\mathrm{Z}, \mathrm{Z}+\mathrm{G}$ and $\mathrm{Z}+\mathrm{GC}$ groups. This might be as a result of the ability of zinc to act as an antioxidant (Powell 2000).

There were relatively low globulin concentrations in the $\mathrm{G}$ and the GC groups compared to the DW group. A relatively high globulin concentration in Roundup ${ }^{\circledR}$ and glyphosate were reported by El-Shenawy (2009). The difference might be due to variation in duration of the experiment, the doses and/or the formulations of the glyphosate, Roundup ${ }^{\circledR}$ and Bush fire ${ }^{\circledR}$ used in this study. On the other hand, zinc alone $(\mathrm{Z})$ and supplementation with zinc was shown to make globulin concentrations relatively high in both the $Z+G$ and the $\mathrm{Z}+\mathrm{GC}$ groups, indicating the antioxidant effect of zinc to regulate metallothionein, a highly conserved low molecular weight cysteine-rich metal chelating antioxidant protein, which was demonstrated to share a lot of features with glutathione (Quesada et al. 1996; Zhou et al. 2007).

The result of this study has shown no significant difference in aspartate aminotransferase (AST) in between the groups; however, there was relatively high AST activity in the $\mathrm{G}$ and the GC groups compared to the DW group. The reason for the apparently high level of serum AST might be associated with some level of damage to any or all of the organs producing this enzyme such as liver, cardiac and skeletal muscles (Ambali et al. 2010b). This result agreed with the finding of Benedetti et al. (2004). Indeed, it has been reported that subchronic exposure to glyphosate caused damage to the liver (Benedetti et al. 2004). On the other hand, the increase in the serum concentration of AST due to exposure to glyphosate was attenuated due to supplementation with zinc in the $\mathrm{Z}+\mathrm{G}$ and the $\mathrm{Z}+\mathrm{GC}$ groups, thus indicating the antioxidant activity of zinc which brought about restoration of the AST activity in rats. The relatively low AST activity in the $\mathrm{Z}$ group compared to the DW group might be due to slight pro-oxidant effect of zinc since the rats were not under oxidative stress.

There were no significant changes in the activity of alanine aminotransferase (ALT) in between the groups. However, there was a relatively high ALT activity in the G and the GC groups compared to the DW group. This elevation in the activity of ALT following subchronic glyphosate exposure in this study agreed with the result of previous studies (Caglar and Kolankaya 2008; El-Shenawy 2009), which reported increased level of ALT in rats which was said to be part of the diagnostic symptoms of liver diseases, and also supported the hypothesis which stated that the increased serum transaminases (ALT and AST) might reflect hepatotoxicity which leads to extensive liberation of enzymes in the blood (Daabees et al. 1992). The reason for the apparently high serum ALT activity in the $\mathrm{Z}$ group is not known for certain, but it might be due to its pro-oxidant effect as reported by Abdallah and Samman (1993) since the rats were not under oxidative stress. Supplementation with zinc in $\mathrm{Z}+\mathrm{GC}$ group attenuated the hepatotoxic effect of the glyphosate on the serum activity of ALT. There was, however, a relatively high ALT activity in $\mathrm{Z}+\mathrm{G}$ group, and the reason for such is not known for certain especially in the light of the attenuated effect observed in $\mathrm{Z}+\mathrm{GC}$ group and might therefore require further studies.

The result of this study showed a relatively low serum activity of alkaline phosphatase (ALP) in the G and the GC groups compared to the DW groups. This is at variance with the previous finding (El-Shenawy 2009) which reported a relatively high ALP activity in rats exposed to Roundup ${ }^{\circledR}$ and glyphosate for 2 weeks, suggestive of damage to hepatocytes, bone, intestine and kidney, which are the sources of this enzyme as reported by Maxam and Gilbert (1980). The reason for the relatively low ALP activity in the glyphosateexposed groups in this study is not known especially in the light of histopathologic lesions observed in the livers of the rats in the $\mathrm{G}$ group, and this might therefore suggest that the agent did not affect the other organs that produce the enzyme since it is not a liver-specific enzyme. On the other hand, supplementation with zinc restored the ALP activity to near normal in both the $\mathrm{Z}$ and the $\mathrm{Z}+\mathrm{G}$ groups, thus reflecting the antioxidant effect of zinc. The reason for the significantly high, $p<0.05$, serum ALP activity in $\mathrm{Z}+\mathrm{GC}$ compared to GC group is not known especially with the non-observable microscopic lesion in the organs of the rats in the group.

There were no significant changes in the serum sodium ion $\left(\mathrm{Na}^{+}\right)$concentration in between the groups. Oxidative stress was shown not to cause significant alteration of $\mathrm{Na}^{+}$in 
earlier studies (Ambali et al. 2007, 2010a; Ambali 2009). However, there was a slightly low $\mathrm{Na}^{+}$concentration in the $\mathrm{G}$ and the GC groups compared to the DW group. These changes might be associated with functional alteration in the proximal tubules due to its nephrotoxic effect. On the other hand, there was a relatively higher decrease in serum $\mathrm{Na}^{+}$ concentration in zinc-treated groups $\mathrm{Z}, \mathrm{Z}+\mathrm{G}$ and $\mathrm{Z}+\mathrm{GC}$, probably because the zinc used was zinc chloride.

The result of this study has shown a relatively high serum potassium $\left(\mathrm{K}^{+}\right)$concentration in the $\mathrm{G}$ and the GC groups compared to the DW group. Oxidative stress due to chlorpyrifos (CPF) exposure was shown to cause relatively high serum $\mathrm{K}^{+}$concentration (Ambali et al. 2010a). The serum $\mathrm{K}^{+}$concentration in zinc ( $\mathrm{Z}$ )-treated group, the $\mathrm{Z}$ and the zinc-supplemented groups, the $\mathrm{Z}+\mathrm{G}$ and the $\mathrm{Z}+\mathrm{GC}$ groups indicated amelioration that resulted in the restoration in the serum $\mathrm{K}^{+}$concentration to near normal, probably due to its antioxidant effect.

This study showed relatively low serum $\mathrm{Cl}^{-}$concentrations in the $\mathrm{G}$ and the $\mathrm{GC}$ groups compared to the $\mathrm{DW}$ group. This marginal variation is apparently associated with functional alteration in the proximal tubules (Krishma and Ramachandran 2009). Supplementation with zinc caused an improvement in the serum $\mathrm{Cl}^{-}$concentration in the $\mathrm{Z}+\mathrm{G}$ and the $\mathrm{Z}+\mathrm{GC}$ groups. The reason for the relatively lower serum $\mathrm{Cl}^{-}$concentration in the $\mathrm{Z}$ group is not clear, but might be associated with the pro-oxidant effect of zinc since the rats were not under oxidative stress challenge.

The serum bicarbonate $\left(\mathrm{HCO}_{3}^{-}\right)$concentration in this study showed relatively higher concentrations in $\mathrm{G}$ group and without noticeable change in the GC group compared to the DW group. This difference might be due to its nephrotoxic effect (Krishma and Ramachandra 2009). Supplementation with zinc in the $\mathrm{Z}+$ $\mathrm{G}$ and the $\mathrm{Z}+\mathrm{GC}$ groups ameliorated the lower $\mathrm{HCO}_{3}^{-}$concentrations in the glyphosate-treated groups. The zinc alone, however, showed a slight difference in serum $\mathrm{HCO}_{3}^{-}$concentration compared to DW group, possibly due to the redox state since supplementation with zinc had ameliorated and resulted in relatively high serum $\mathrm{HCO}_{3}^{-}$concentration.

The result of serum calcium ion $\left(\mathrm{Ca}^{2+}\right)$ concentration in this study showed relatively low $\mathrm{Ca}^{+}$concentrations in the $\mathrm{G}$ and the $\mathrm{GC}$ groups compared to the DW group. On the other hand, supplementation with zinc restored the serum $\mathrm{Ca}^{2+}$ concentration to relatively higher level in the $\mathrm{Z}+\mathrm{G}$ group, and it was even highly significant $(p<0.001)$ in the $\mathrm{Z}+\mathrm{GC}$ group compared to the $\mathrm{G}$ and $\mathrm{GC}$ groups; the effect was highly significant $(p<0.01)$ in the $\mathrm{Z}+\mathrm{GC}$ group compared to $\mathrm{Z}+\mathrm{G}$ group and significant $(p<0.05)$ in $\mathrm{Z}+\mathrm{GC}$ group compared to $\mathrm{Z}+\mathrm{G}$ group. The high $\mathrm{Ca}^{+}$concentration recorded in $\mathrm{Z}+\mathrm{GC}$ group might be due to intestinal absorption of calcium as reported by Spencer et al. (1987) in their study on the effect of zinc supplementation on the intestinal absorption of calcium, who reported that at high concentration of $\mathrm{Ca}^{2+}$, high $\mathrm{Zn}^{2+}$ intake did not affect the intestinal absorption of calcium since Yamaguchi (1998) reported that zinc is required for osteoblastic activity by activating the aminoacyl tRNA synthetase in the osteoblastic cells, and Holloway et al. (1996) reported that zinc treatment inhibits bone resorption, or it might be as a result of dystrophic calcification. In the $\mathrm{Z}$ group, however, the $\mathrm{Ca}^{2+}$ concentration showed no noticeable difference with the DW group, thus underscoring the antioxidant effect of zinc.

The serum phosphate $\left(\mathrm{PO}_{4}^{-}\right)$concentration in this study showed a relatively higher serum $\mathrm{PO}_{4}^{-}$concentration in the $\mathrm{G}$ and the $\mathrm{GC}$ groups compared to the DW group. On the other hand, supplementation with zinc ameliorated the increase in the serum $\mathrm{PO}_{4}^{-}$concentration in the $\mathrm{Z}+\mathrm{G}$ and the $\mathrm{Z}+\mathrm{GC}$ groups. In the $\mathrm{Z}$ group, however, there was slightly high $\mathrm{PO}_{4}^{-}$concentration, possibly due to the pro-oxidant effect of zinc.

The present study demonstrated that subchronic exposure to glyphosate caused relatively high serum urea concentration in the $\mathrm{G}$ and the GC groups compared to the DW group. This finding is in agreement with those reported by Caglar and Kolankaya (2008) who studied the effect of 56 and $560 \mathrm{mg} / \mathrm{kg} /$ day Roundup ${ }^{\circledR}$ and glyphosate and reported increased level of urea by 2.1 -fold and 1.9-fold compared to the control, respectively. The elevation of blood urea is a good indicator for kidney dysfunction. On the other hand, administration of zinc alone resulted into a slightly high serum urea concentration in the $\mathrm{Z}$ group and relatively high in the $Z+G$ group. The reason for the slight elevation of urea in the $\mathrm{Z}$ group might be due to the pro-oxidant effect of zinc, whereas the reason for the relatively high urea concentration in the $\mathrm{Z}+\mathrm{G}$ group is not known for certain, but it might be associated with the high exposure and therefore might require high dose of zinc since supplementation with zinc was able to ameliorate the elevated urea level in the $\mathrm{Z}+\mathrm{GC}$ group.

The result of this study showed a relatively high serum creatinine concentration in the $\mathrm{G}$ and the GC groups compared to the DW group. This result is in agreement with the result of an earlier study by Caglar and Kolankaya (2008) who reported a relatively high creatinine concentration following exposure to Roundup ${ }^{\circledR}$ in rats, which was said to be possible indicator of kidney dysfunction. The relatively high serum creatinine concentrations were ameliorated in the $\mathrm{Z}+\mathrm{G}$ and $\mathrm{Z}+\mathrm{GC}$ groups. Administration of zinc alone, however, caused a slightly high serum creatinine concentration when compared to DW group, and the reason for that is not clear but might be associated with pro-oxidant effect of zinc.

Open Access This article is distributed under the terms of the Creative Commons Attribution License which permits any use, distribution, and reproduction in any medium, provided the original author(s) and the source are credited. 


\section{References}

Abdallah SM, Samman S (1993) The effect of increasing dietary zinc on the activity of superoxide dismutase and zinc concentration in erythrocytes of healthy female subjects. Eur J Clin Nutr 47:327-332

Amara S, Abdelmelek H, Garrel C, Guiraud P, Douki T, Ravanat J, Favier A, Sakly M, Ben RK (2008) Preventive effect of zinc against cadmium-induced oxidative stress in the rat testis. $J$ Reprod Dev 54(2):129-134

Ambali SF (2009) Ameliorative effect of vitamin C and E on neurotoxicological, haematological and biochemical changes induced by erythrocte osmotic fragility in Wistar rats. $\mathrm{PhD}$ thesis. Ahmadu Bello University, Zaria, $356 \mathrm{p}$

Ambali SF, Abubakar AT, Shittu M, Yaqub SL, Anafi SB, Abdullahi A (2010a) Chlorpyrifos-induced alteration of haematological parameters in Wistar rats: ameliorative effects of zinc. Res J Environ Toxicol 4:55-66

Ambali SF, Akanbi DO, Igbokwe N, Shittu M, Kawu M, Ayo J (2007) Evaluation of subchronic chlorpyrifos poisoning on haematological changes in mice and protective effect of vitamin C. J Toxicol Sci 32:111-120

Ambali SF, Onukak C, Idris SB, Yaqub SL, Shittu M, Aliyu H, Kawu MU (2010b) Vitamin C attenuates short-term hematological and biochemical alterations induced by acute chlorpyrifos exposure in Wistar rats. J Med Med Sci 1(10):465-477

Ayoola SO (2008) Histopathological effects of glyphosate on juvenile African catfish (Clarias gariepinus). American-Eurasian J Agric Environ Sci 4(3):362-367

Belongia EA, Berg R, Liu KA (2001) A randomized trial of zinc nasal spray for adults. Am J Med 111(2):103-108

Benedetti AL (2004) Vituri C, Trentin AG, Domingues MAC, AlvarezSilva M (2004) The effects of sub-chronic exposure of Wistar rats to the herbicide glyphosate-Biocarb. Toxicol Lett 153:227-232

Beuret CJ, Fanny Z, Maria SG (2004) Effects of the herbicide glyphosate on liver lipoperoxidation in pregnant rats and their fetuses. Reprod Toxicol 19(4):501-504

Caglar S, Kolankaya D (2008) The effect of sub-acute and sub-chronic exposure of rats to the glyphosate based herbicide Roundup. Environ Toxicol Pharmacol 25:57-62

Cox C (1995) Herbicide factsheet: glyphosate, part 1: toxicology. J Pestic Reform 15:3

Daabees AY, El-Damiaty NA, Soliman SA, El-Toweissy MY (1992) Comparative action of three synthetic pesticides on serum, liver, brain of the freshwater fish, Clarias lazera. J Egypt Ger Soc Zool 9(A):105-109

El-Shenawy NS (2009) Oxidative stress responses of rats exposed to Roundup ${ }^{\circledR}$ and its active ingredient glyphosate. Environ Toxicol Pharmacol 28(2009):379-385

Franz JE, Mao MK, Sikorski JA (1997) Glyphosate: a unique global herbicide. ACS Monograph 189. American Chemical Society, Washington

Holloway WR, Collier FM, Herbst RE, Hodg JM, Nicholson GC (1996) Osteoblast-mediated effects of zinc on isolated rat osteoclasts: inhibition of bone resorption and enhancement of osteoclast number. Bone 19(2):137-142

Krishma H, Ramachandran AV (2009) Biochemical alterations induced by the acute exposure to combination of chlorpyrifos and lead in Wistar rats. Biol Med 1(2):1-6

Kumar A, Malhotra A, Nair P, Garg M, Dhawan DK (2010) Protective role of zinc in ameliorating arsenic-induced stress and histopathological changes in rat liver. J Environ Pathol Toxicol Oncol 29(2):91-100

Malik J, Barry G, Kishore G (1989) The herbicide glyphosate. Biofactor 2:17-25

Maxam AM, Gilbert W (1980) Sequencing end-labeled DNA with base-specific chemical cleaves. Methods Enzymol 65(1):499-560

McClain CJ, Staurt M, Vivian B (1992) Zinc status before and after zinc supplementation of eating disorders in patients. J Am Coll Nutr 11:694-700

Modesto KA, Martinez CBR (2010) Effects of Roundup ${ }^{\circledR}$ Transcorp on fish: hematology, antioxidant defences and acetylcholinesterase activity. Chemosphere 81:781-787

Olurunsogo O, Bababunmi E, Bassir O (1979) Effect of glyphosate on rat liver mitochondria in vivo. Bull Environ Toxicol $2: 257-264$

Powell SR (2000) The antioxidant properties of zinc. J Nutr 130:1447S$1454 \mathrm{~S}$

Quesada AR, Byrnes RW, Krezoski SO, Pettering DH (1996) Direct reaction of $\mathrm{H}_{2} \mathrm{O}_{2}$ with sulfhydryl groups in HL-60 cells: zinc-metallothionein and other sites. Arch Biochem Biophys 334:241-250

Rebecca LT, Guang-Yang Y, Wei-Jin T, Hsiao-min C, Jou-Fang D (1991) Survey of glyphosate-surfactant herbicide ingestion. Clin Toxicol 29(1):91-109

Rostan EF, DeBubys HV, Madey DL, Pinnell SR (2002) Evidence supporting zinc as an important antioxidant for skin. Int $\mathrm{J}$ Dermatol 4(9):606-611

Spencer H, Rubio N, Kramer L, Norris C, Osis D (1987) Effect of zinc supplements on the intestinal absorption of calcium. J Am Coll Nutr 6(1):47-51

Tizhe EV (2012) Influence of zinc supplementation on the pathology of subchronic exposure of Wistar rats to glyphosate. Unpublished M.Sc. thesis. School of Postgraduate Studies, Ahmadu Bello University, Zaria

Vivian DCL, Claudia BRM (2007) Toxicity and effects of a glyphosatebased herbicide on the neotropical fish Prochilodus lineatus. Comp Biochem Physiol C: Toxicol Pharmacol 147(2):222-231

Vosilinko V, Grebenev A (1990) Internal diseases. Jordan Journal of Biological Sciences, p 406

World Health Organization (1994) Glyphosate environmental health criteria No. 159. WHO, Geneva, p 177

Yamaguchi M (1998) Role of zinc in bone formation and bone resorption. J Trace Elem Exp Med 11:119-135

Zhou Z, Kang X, Jiang Y, Song Z, Feng W, Mcclain CJ, Kang YJ (2007) Preservation of hepatocyte nuclear factor-4a is associated with zinc protection against TNF- $\alpha$ hepatotoxicity in mice. Exp Biol Med 232:622-628 